\title{
CORPORATE SOCIAL CAPITAL
}

\begin{abstract}
This paper discusses the concepts of stakeholder, reputation and social capital and their relevance for corporations in modern society. The paper argues that there is a special demand for reputation management in today's corporate communications and public relations due to fragmented publics and stakeholders, as well as to increased public interest in corporations. The introduction of real-time media has also imposed new demands which corporations today must meet to survive. Different stakeholders possess the ability to benefit but also to harm the corporations through corporate reputation. Cultivated stakeholder relations can be especially beneficial to corporate reputation and long-term development, and the social ties that stakeholders embody can even be seen as social capital for the corporation. A new concept of "Faith-holders" is also presented to better describe corporate social capital.
\end{abstract}

Keywords: social capital, corporations, stakeholders, reputation, faith-holders.

\section{RESUMEN}

Este artículo habla de los conceptos de stakeholders, reputación y la capital social y su importancia para corporaciones en la sociedad moderna. El artículo argumenta que hay una demanda especial de la dirección de reputación en comunicaciones corporativas de hoy y relaciones públicas debido a públicos fragmentados y stakeholders, así como al interés aumentado público a corporaciones. $\mathrm{La}$ introducción de medios de comunicación en tiempo real también ha impuesto las nuevas demandas que las corporaciones hoy deben encontrar para sobrevivir. stakeholders diferentes poseen la capacidad de beneficiarse, pero también dañar las corporaciones por la reputación corporativa. Relaciones de stakeholders cultas pueden ser sobre todo beneficiosas a la reputación corporativa y el desarrollo a largo plazo, y los lazos sociales que los stakeholders incorporan aún puede ser visto como la capital social para la corporación. Un nuevo concepto "Faith-holders" también es presentado para describir mejor una corporación de capital social.

Keywords: Capital social, corporaciones, stakeholders, reputación, faith-holders.

\section{Face IssN 1794-9920}

Recepción: Julio de 2008

Revisión: Diciembre de 2008

Aceptación: Diciembre de 2008 


\section{INTRODUCTION}

“...corporations practicing stakeholder management will, other things being equal, be relatively successful in conventional performance terms" (Donaldson \& Preston 1995, 67).

Stakeholder theory is often used as a framework for understanding the relationship between a corporation and its environment. This relationship has become more important as corporations recognize that they are operating in an environment containing publics, distinct groups of people and corporations that have an actual or potential interest and impact on their existence. The turbulent world around corporations constantly poses new demands and threats. The promised benefit of stakeholder theory is increased efficiency, an important value in the quarterly economy (Clarkson 1995, 78).

The focus in stakeholder research is to define how the corporation behaves in relation to its stakeholders, and what the stakeholders think of this behavior (Bromley, 1993; Fombrun, 1996). The different stakeholders are believed to continually form assessments of the corporation, and together these various assessments form an invisible entity of attitudes, the corporation's intangible operating environment. The assessments are formed individually in the eye of the beholder, regardless of whether the target actively attempts to influence them or not. How stakeholders perceive the corporation will for better or worse influence their behavior (Davies, Chun, da Silva \& Roper, 2004).

Although stakeholder assessments cannot be manipulated toward desired outcomes, corporations make a considerable impact on stakeholder opinions through means of public relations (see Grunig et al., 1992; Bromley, 1993; Fombrun \& van Riel, 2003; Pharoah, 2003). In order to survive (and be legitimate), a corporation needs to influence its environment to view its operations in a favorable light. Yet in order for the corporation to achieve this objective, it must highlight its actual deeds, since false claims arouse distrust and indignation in stakeholders. Influence is achieved via communication, and the desired outcome is often described as a relationship of twoway communication between the corporation and its stakeholders. Maintaining a dialogue is especially important as stakeholders today have access to information and are empowered to act through various real time media. Issues, opinions and alternative points of view travel rapidly through public perceptions and the media. The speed at which the media pick up on current events is also a challenge for corporations, as the increasingly mediated information that stakeholders now receive places a special emphasis on trust (Bentele, 2005). This ever-changing environment requires corporations to remain constantly aware of both old and new stakeholders. 
New demands have also arisen from stakeholders and publics. Business as usual is no longer enough; instead what is needed is increased transparency as well as simplification of issues and standpoints through public relations. It has been argued that the causes of these new demands and expectations are due to the fragmentation of publics and stakeholders, as well as increased public interest in corporations. The serious losses and crises that have affected highly esteemed corporations have also contributed. These changes are especially visible in traditional hierarchical corporations as they are forced out of their status quo and into the market of openness, transparency and intangible assets.

The role of today's corporations could well be described by the metaphor of floor-ball, a favorite European indoor sport (salibandy, Markkanen 1999; Luoma-aho, 2005). Floor-balls are white, perforated, light and no so fast-moving balls that do little damage outside the playing-field. The ball is about the size of a baseball, yet made of plastic and hence hollow and weightless. It has several perforations, and each hole affords a different view in the ball representing today's fragmented stakeholders, who all see the corporation from their own point of view. The metaphor also captures the heightened public interest and the need arising of it for openness and transparency. Outside of the corporate world, the ball receives little attention, and it is quite slow. But when on the field, the game moves fast and the ball changes direction constantly, even in mid-air.

The speed of this game resembles the environment corporations today face. The different stakeholders form one central part of that environment.

The concept of social capital is rather new to the context of corporations. This paper joins together social capital with stakeholder thinking, by arguing that cultivated stakeholder relations and reputation add up to corporate social capital. First, the corporation and its stakeholders are described. Second, an introduction to the concept of social capital is provided. Finally, stakeholder relations and good reputation are argued to provide corporations with advantages that could even be described as corporate social capital.

\section{CORPORATE WORLD}

"We live in an organizational society and if we do not make at least an effort to understand organizational phenomena we run the danger of becoming victimized by them. It is small comfort to complain about bureaucracy, to laugh at organizational inefficiency, or to fear organizational power to control our lives. What we must seek is sufficient understanding to be able to influence organizations." (Schein 1994, 212.) 
A corporation is a legally organized entity with rights and responsibilities, separate from its owners and members. A corporation can metaphorically be compared to a natural person, consisting of different parts, functions as well as an identity (Hatch, 1997). A corporation is an organizations, and thus "a complex set of independent parts that interact to adapt to a constantly changing environment in order to achieve its goals" (Kreps 1990, 94). To Schein $(1994,15)$, an organization is the planned coordination of activities of a number of people trying to achieve a shared purpose through division of labor and responsibilities.

People organize, because it is functional and efficient; efficiency has been described in economic terms as a reduction in transaction costs between parties interacting repeatedly, even if their interests conflict (Williamson, 1985). Transaction costs are understood as costs outside the actual exchange, those required to maintain the contract. People organize to receive a positive individual balance to their own needs and the needs of others (Abrahamsson, 1975). It is necessary for effectiveness and productivity of an organization to be united, for the members of the organization to possess clear purposes and aims. Jawahar \& McLaughlin $(2001,412)$ add that "The complexity of organizations and organizational phenomena guarantees that theories and models, especially universal ones, cannot give a complete representation." Thus in discussing corporations, it is always the individual interpretations that are discussed.

Moreover, disciplines view organizations and corporations differently: in sociology an organization is a set of people occupying roles and statuses. On the other hand, in political science an organization is viewed as a set of power relations. Economics understands organizations as sets of people attempting to maximize their utilities. In marketing the interest is in the role of the organization in its markets, and its interaction with its environment, its publics, and the stakeholders. (Kotler 1975.) In organizational communications and PR the organization is a construct of networks upheld through communication.

The traditional thinking of corporations acknowledges only shareholders; they hold stocks and thus partly ownership of the corporation. However, every corporation operates within an environment of publics, distinct groups of people and organizations that have an actual or potential interest and impact on the corporation. Moreover, a company creates publics for itself, as its functions influence and affect those around it (Grunig, Dozier, Ehling, Grunig, Repper \& White 1992). These interests are addressed in stakeholder thinking. 


\section{STAKEHOLDER THINKING}

Stakeholders are defined as those groups which aim to influence or are influenced by the corporation, or groups without which the corporation would cease to exist, according to the Stanford Research Group (1963 in Freeman 1995). Stakeholder thinking differs from other theories in that "...it is intended to both explain and guide the structure and operation of the established corporation. Toward that end it views the corporation as an entity through which numerous and diverse participants accomplish multiple, and not always entirely congruent, purposes" (Donaldson \& Preston 1995, 70). For an overview of what is meant by stakeholder thinking, four premises underlying stakeholder thinking are assumed to hold in this paper (see Jones \& Wicks 1999, 207):

1. A corporation has relationships with many constituent groups, stakeholders. (Freeman 1984)

2. The concern of stakeholder theory is with the nature of these relationships as well as their outcome for both the corporation and its stakeholders.

3. The interests of all (legitimate) stakeholders have intrinsic value, and no set of interests is assumed to dominate over others. (Clarkson 1995, Donaldson \& Preston 1995)

4. Stakeholder theory is focused on managerial decision-making (Donaldson \& Preston 1995), and is thus somewhat corporation-centered.

As the corporation is not always able to meet the needs of all stakeholders equally, various typologies have been developed as a guide to the order in which stakeholders should be addressed and ranked. Stakeholders are often categorized into primary and secondary stakeholder groups. Primary stakeholders have formal contracts with the corporation (Carroll, 1993), while secondary stakeholders are those who are not engaged in significant exchange or seen as essential to the corporation's survival (Clarkson, 1995). Other categorizations refer to importance, closeness or type of relation. Stakeholders can also be grouped into internal (permanent relation) and external coalitions (Näsi 1979). Distinguishing different groups is helpful for the corporation, yet it is vital to remember that the members of these groups are in constant flux.

Pizzorno (2004) distinguishes between active and dormant circles of stakeholders: active circles generate opinion and reputation through discussion, whereas dormant circles do not affect reputation formation, whether out of lack of knowledge, experience or discussion. Stakeholders can further be distinguished according to their different traits or environments: economic, technological, social and political (Carroll 1993). Savage, Campbell, Patman \& Nunnelley (2000, 103) distinguish stakeholders according to their past and present potential to cooperate with or threaten the 
corporation. They differentiate between marginal stakeholders with a low level of cooperation or threat, and supportive and non-supportive stakeholders. The most important stakeholders, however, are the "mixed blessing" stakeholders. They have the power both to cooperate with and to threaten the corporation.

Stakeholder categorizations discriminate between individuals on the basis of how much relevance or influence they have. This is understandable, as corporate resources are limited. However, there are arguments against drawing such distinctions. The importance of stakeholder groups changes, for example, with the corporate life cycle (Jawahar \& McLaughlin, 2001). The attention stakeholders require also varies as their importance to the corporation grows or diminishes over time. Secondary or dormant stakeholders can change their status and quickly become primary and active. Moreover, categorizing stakeholders can create an artificial and false sense of order and therefore all stakeholders should be seen as having a potential stake in the organization and therefore primary (Fombrun \& van Riel, 2003). To conclude, in a chaotic world that has already proven the importance of "the butterfly effect" (Lorenz, 1963: sensitive dependence on initial conditions), stakeholder relations are becoming an ever more vital part of organizational survival. Monitoring stakeholder relations offers corporations a much needed hint of predictability.

Freeman $(1995,39)$ suggests that there is no single well-developed stakeholder theory, but that stakeholder thinking can be seen as a type of human value creating metaphor. Stakeholders are often considered to need "management", a term which implies that stakeholders are somehow controllable. Traditionally management can also include the wielding of power and hierarchy. Lately there has been a move away from controlling and managing, towards collaboration. Ongoing dialogue is one of the main emphases of the theory on stakeholder enabling (Calton \& Kurland, 1996), as it directs attention to the joint creation of meanings, the building of ethical regulations and trust formation.

Stakeholder enabling has the difficult goal of bringing all stakeholder groups into dialogue and creating a mutual understanding of the direction to be followed (Calton \& Kurland, 1996, 154-170). The notion of enabling explains the importance of the quality of the relationship, as communications between a corporation and its stakeholders is more two-way than one-way. It also explains stakeholder thinking as a bridge between the corporation and its stakeholders. Enabling also indicates acting together and sharing responsibility, thus removing the confrontational setting from the organizationstakeholder relationship. This interdependency involves shared information, a similar understanding of the concepts applied, and ongoing dialogue as customary features of the corporation. 


\section{STAKEHOLDER REPUTATION AND MANAGEMENT}

How the stakeholders perceive the corporation is a sum of many factors. Stakeholder perceptions together form a collective record of the past deeds of the corporation, its reputation (Sztompka, 2000; Fombrun \& van Riel, 2003). Reputation is not equal to being known, but being well-known may contribute to a good reputation (Rindova, Williamson, Petkova \& Sever, 2005). Reputation is formed differently depending on the directness of the situation itself and the amount of contact (Fombrun, 1996): reputation can be mediated or predicated merely on the level of stories told, in cases where the stakeholders have little or no personal contact with the corporation. On the other hand, stakeholders may experience the corporation indirectly through its products or services or employees (Aula \& Heinonen, 2002). However, the most credible source and most influential factor for reputation formation is personal experiences (Pizzorno, 2004), as "knowing" is more credible than "seeming" or "hearing".

Reputation formation also depends on the relationship between the stakeholders and the corporation. Stakeholders have different levels of legitimacy, power and urgency of claims in respect to the corporation (Mitchell et al., 1997). Frequency of collaboration and contact are also vital for reputation formation, and especially for the strength of beliefs about the corporation (Luoma-aho, 2005). Those with frequent contact with the corporation have more personal interaction, whereas those with less actual contact rely on other means in forming their opinions (such as the media or other people). The frequent stakeholders are especially vital for reputation formation, as there is more of a chance to develop a relationship and follow the corporate developments over time.

There are many factors affecting the way corporations and their messages are perceived, and the desired reputation (organizational target reputation) may differ from the outcome (perceived or stakeholder reputation) (Luoma-aho, 2007). Moreover, reality often lies somewhere in between the corporation's aim and the stakeholder's perceptions. This gap is often filled with PR actions such as profile building, information providing, listening and dialogue, marketing and environmental scanning.

Managing reputation, however, is a complex issue. On the one hand, reputation should result from actions hence a good reputation would arise out of good and just actions without any effort or communication. Here the argument is that the most credible reputation results from satisfied stakeholders sharing their experiences informally in various social networks (Sjovall \& Talk, 2004). This approach is adopted by many traditional, hierarchical corporations and organizations, but alone is seldom sufficient.

Moreover, good deeds do not benefit the corporation if they are not known. On the other hand, there is the belief that good reputation requires management, and since reputation is connected with what is said, it can be managed for example, by 
monitoring mentions about the corporation in everyday conversations and in the media.

\section{CORPORATIONS AND SOCIAL CAPITAL}

In a world that is constantly changing and full of risks, a world where networks are a necessity, corporations capable of utilizing their social networks and establishing a good reputation and trust among their stakeholders are said to survive the best (Patulny, 2003). In fact, nations capable of creating a culture of trust are reported to be on many levels the most successful; they have a higher gross national product, there is less corruption, their citizens are more satisfied and crime-rates are lower (see for example Eurobarometer; Transparency International). These social networks and the trust within them are referred to as social capital (Lin 2001, Putnam 1993). Countries with strong social networks and a culture of trust are said to have high levels of social capital. Just like physical capital, social capital may exist on both the individual and the collective level. "The more people in a society (or a corporation) who have many and widespread social relationships with people they believe are trustworthy, the greater becomes access to social capital in the society (or corporation)." (Rothstein 2003, 112.)

The term social refers to interactions, whereas capital refers to an asset to be disposed of. Diverse social and individual benefits have been attributed to social capital, including health, happiness, tamed ethnic conflict and reduced violence, as well as good institutional performance. Social capital has been linked to successful democracy, political rights and civil liberties, while countries and cultures with repressive governments are said to erode social capital by discouraging trust and spontaneous group activity (Putnam, 1993). Social capital has even been argued to contribute to economic growth and welfare (Fukuyama, 1995). It is associated with increased interaction and coordination of operations (Ruuskanen, 2001), and said to boost achievement as cooperation becomes frequent and social ties enable the formation of trust. Though the concept is quite new, its contents are old: the benefits of joint action and collaboration have long been studied.

Social capital is understood to consist of three elements: social networks, trust and reciprocity. The OECD (Organization for Economic Cooperation and Development) defines social capital as "networks together with shared norms, values and understandings that facilitate cooperation within or among groups" that serve to foster important social outcomes such as voluntary activity and confidence in government and institutions of governance (Patulny 2003). Social capital is concerned with relations between people and the various kinds of capital embedded in and mobilizable through those relations. Social capital may be defined from the corporate point of view as "the extent of the resources available to a corporation through networks of trust and 
reciprocity among its stakeholders" (Luoma-aho, 2005, 150). Such resources would include a good reputation, less turnover and lower transaction costs as well as better innovations and more satisfied customers and stakeholders.

Social capital takes time to develop. Once created and set in motion, social capital feeds on itself. Granowetter concludes that past relationships of trust lead to similar relationships in the future; in other words, past social capital provides new social capital (Granowetter, 1985). Often social capital is understood, as Coleman (1988, 98-102) suggests, as a resource for action; for him the forms of social capital are obligations and expectations, information channels, and social norms. Coleman notes that social capital has a certain obligation of reciprocity, and that there is usually a delay between a favor and its being returned. This delay requires trust, as trust bridges the gap between the favors. Coleman emphasizes the solidity of social relations and the corporation's ability to trust, maintain norms and mediate information. Strong social networks allow norm control and keep an organization bound together: social capital is a lubricant for efficient action. Moreover, social capital must be relational, as it deals with perceptions and assessments of relationships (Rothstein 2003). The essence of the theory of social capital is to describe the process by which resources are captured through investments in social relations (Lin 2005).

In the debate on social capital, the type of social ties has also been of interest. Mark Granowetter (1973) emphasizes the importance of weak ties: strong networks have ties to the ego and are essentially closed information networks, whereas weak ties move in circles different from the ego's and have access to different information. He claims that it is weak ties (close to what Putnam 2000 calls bridging social capital) that make or break the existence of social capital. If the ties are strong, social capital is not necessarily a positive concept. Groups with tight social cohesion and abundant interpersonal trust can be a source of destructive actions within the group or towards society at large.

Ojala, Hakoluoto, Hjorth \& Luoma-aho (2006) define social capital as both good and bad depending on the point of analysis: on the individual level it is almost always a positive phenomena, yet on the societal level the individual benefits could lead to unwanted consequences, as in the case of gangs, crime and exclusion.

Cooperation, whether with stakeholders or within the corporation, is facilitated by social capital, and social capital is made productive through communication (Putnam, 1993). Thus communication can be seen as the catalyst or even means of social capital. "Social capital can be understood as the intangible capital of society that is manifested in trusting relationships between parties and enables official functions." (Lehtonen 2000,194 .) In fact, communication as such can be understood to have capital value, it may be a form of social capital an sich; in our communication-entrenched society the chance to be heard and understood or even listened to is not axiomatic (Luoma-aho, 2005b). Moreover, trusting relations are upheld through open and honest 
communication, and this makes social capital a central issue for communication research.

\section{CORPORATE SOCIAL CAPITAL}

The modern corporate environment lays a special emphasis on transparency and equality, and the corporation has a social responsibility to collaborate with and enable its stakeholders. Stakeholder theories are understood as beneficial for corporations, but this thinking does not include all types of stakeholders. Some stakeholders are more valuable than others, and some are more beneficial for the corporation in the long run. Moreover, some stakeholders do not contribute to corporate social capital, but may prove to be quite problematic or even dangerous for corporate survival, especially if the various groups are not recognized or included. Further, not all contact of individuals in corporations count as social capital, as they may not be resources on the corporate level, but merely individual contacts. Frequency plays a role, as a relationship is better formed with repeated interactions. This paper suggests that it is the frequent stakeholders, those with ongoing interaction with the corporation that are the most beneficial to the corporation. Why?

First, stakeholders who have actual experiences of the corporation are the most credible source when it comes to the reputation and trustworthiness of the corporation (Pizzorno, 2004; Luoma-aho, 2005). It is one thing to make an impression based on a single event, meeting or product, but quite another to keep someone satisfied and happy over a long period of time. Moreover, frequent stakeholders see both the good times and the tough times had by the corporation, and thus acquire a more holistic view of the corporate entity. These are stakeholders who can actually estimate whether the improvements the corporation makes are visible in daily practice. If the frequent stakeholders are dissatisfied, they are not afraid to voice their complaints in several various communication networks including friends, coworkers and family. On the other hand, if the frequent stakeholders are satisfied, they spread their satisfaction through these highly trusted peer-networks, and build the corporate reputation much more effectively than it is done by the traditional corporate efforts, such as advertising.

Elsewhere I (Luoma-aho, 2005) have argued for a new concept to better describe the corporate social capital that stakeholders provide. The new concept of "Faith-holders" describes stakeholders with high levels of trust in the corporation combined with frequent, reoccurring contact. They are the silent masses of stakeholders that deal with the corporation frequently, who make up the foundations of corporate reputation. Faith-holders are people like us, and when publics and audiences grow tired of marketing and spin, "a person like me" is the most trusted source of information (Edelman Trust Barometer, 2006). Faith-holders are understood to contribute most to 
the legitimacy of corporations in the $21^{\text {st }}$ century, with the increasing importance of personal networks. Faith-holders may or may not trumpet their existence, and the corporation may or may not acknowledge them. The frequency of contacts (past \& future), however, is understood as especially relevant to the formation of reputation. Moreover, personal contact with a corporation is understood to be the most credible basis for assessment and reputation (Bromley 1993, Aula \& Heinonen 2002). In crises situations or in the case of mixed messages, personal experience has greater credibility than media reports or rumours.

Frequent stakeholders are the founding pillars of the corporate reputation, as they are the most credible source with personal experiences. Should the assessments of those in frequent contact be positive, this will be highly advantageous for the corporation and create a positive reputation. As social capital is defined as resources available through social networks, stakeholders could even be taken as social capital, as they represent a definite resource for the corporation. Turning stakeholders into faith-holders would then be a process of enhancing trust among those with frequent contact.

Corporations practicing public relations and reputation management are in fact already in the process of turning stakeholders into faith-holders, or enhancing trust among those with frequent contact. Increased mediation of communication and information overload underline the importance of reliable sources of information. Stakeholders with personal experiences play a key role, as recommendations and reputation become more valuable. Despite this trend, many corporations still seem to concentrate on one-time only stakeholders. Focusing attention on and ensuring that frequent stakeholders are satisfied would be a strategic choice for future legitimacy.

\section{REFERENCES}

- Abrahamsson, B. (1975). Organisationsteori. Om byråkrati, administration och självsyre. (in Swedish: "Organization theory. On bureaucracy, administration and self governance") Awe/Gebers: Stockholm.

- Aula, P. \& Heinonen, J. (2002). Maine. Menestystekijä. (In Finnish: Reputation, The Success maker.) WSOY: Helsinki.

- Bentele, G. (2005). Vertrauen und Glaubwürdichkeit. Begriffe, Ansätze, Forschungsübersicht und praktische Relevanz. (In German: “Trust and Credibility. Concepts, formation, a research overview and practical relevance") In Bentele, G., Fröhlich, R. \& Szyszka, P. (eds.) Handbuch Public Relations (In German: "Handbook of Public Relations"). Verlag für Sozialwissenschaften: Wiesbaden.

- Bromley, D.B. (1993). Reputation, Image and Impression Management. Wiley: West Sussex. 
- Calton, J.M. \& Kurland, N.B. (1996). A theory of Stakeholder Enabling. Giving voice to an Emerging Postmodern Praxis of Organizational Discourse. In Boje, D.M., Gephart, Jr, R.P. \& Thatchenkery, T.J. (eds.). Postmodern management and organizational theory. Sage: Thousand Lakes.

- Carroll A. B. (1993). Business and Society. Ethics and Stakeholder Management. 2nd Edition. South-Western Publishing: Cincinnati.

- Clarkson, M.B.E. (1995). A Stakeholder Framework for Analyzing and Evaluating Corporate Social Performance. Academy of Management Review. Vol. 20, No. 1, pp. 92-117.

- Coleman, J. S. (1988). Social Capital in the Creation of Human Capital. American Journal of Sociology, Vol. 94, Supplement: Organizations and Institutions: Sociological and Economic Approaches to the Analysis of Social Structure, pp. S95-S120.

- Davies, G., Chun, R., da Silva, R. V. \& Roper, S. (2004). A corporate Character Scale to Assess Employee and Customer Views of Organizational Reputation. Corporate Reputation Review. Vol 7, No. 2, pp. 125-146.

- Donaldson, T. \& Preston, L. (1995). The stakeholder theory of the corporation: Concepts, evidence, implications. Academy of Management Review. No. 20, pp. 65-91.

- Edelman Trust Barometer (2006) [online] [cited 1.9.2006] <URL: http://www.edelman.com/image/insights/content/FullSupplement.pdf\#search= $\% 22$ Edelman $\% 20$ Trust $\% 20$ Barometer $\% 20(2006) \% 22>$

- Eurobarometer (2005). Public opinion in the European Union. [online] [cited 18.4.2006]. $<\mathrm{URL}$ : http://ec.europa.eu/public_opinion/archives/eb/eb64/eb64_en.htm >

- Fombrun, C. \& van Riel, C. (2003). Fame and Fortune: how successful companies build winning reputations. Prentice Hall: Upper Saddle River.

- Fombrun, C. J. (1996). Reputation. Realizing Value from the Corporate Image. Harvard Business School: Boston.

- Freeman, R.E. (1995). Stakeholder thinking: The State of the Art. In Näsi, J. (ed.). Understanding Stakeholder Thinking. LSR-julkaisut: Jyväskylä.

- Freeman, R.E. (1984). Strategic Management: A Stakeholder Approach. Pitman: Boston.

- Fukuyama, F. (1995). Trust: The Social Virtues and the Creation of Prosperity. Free Press: New York.

- Granowetter, M. (1985). Economic action and social structure: The problem of embeddedness. American Journal of Sociology. No. 91, pp. 481-510.

- Granowetter, M. (1973). The Strength of Weak Ties. American Journal of Sociology, No. 78, 6, pp. 1360-1380. 
- Grunig L., Grunig J. \& Ehling W. (1992). What Is an Effective Organization? In Grunig, J. Dozier, D., Ehling, W. Grunig, L., Repper, F \& White, J. (eds.) Excellence in Public Relations and Communication Management. Lawrence Erlbaum Associates: Hillsdale NJ, pp. 65-90.

- Grunig, J., Dozier, D., Ehling, W. Grunig, L., Repper, F. \& White, J. (Eds.) (1992). Excellence in Public Relations and Communication Management. Lawrence Erlbaum: Hillsdale, NJ.

- Hatch, M. (1997) Organization Theory. Modern Symbolic and Postmodern Perspectives. Oxford University Press: New York.

- Jawahar, I. M. \& McLaughlin, G. L. (2001). Toward a descriptive stakeholder theory: an organizational life cycle approach. Academy of Management Review. Vol. 26, No. 3, pp. 397-414.

- Jones, T. M. \& Wicks, A. C. (1999). Convergent stakeholder theory. Academy of Management Review, No. 24, pp. 206-221.

- Kreps, G. L. (1990). Organizational Communication: Theory and practice. 2nd edition. Addison-Wesley: New York.

- Kotler, P. (1975). Marketing for nonprofit-making organizations. Prentice-Hall: Engelwood Cliffs, New Jersey.

- Lehtonen, J. (2000). Toimiva viestintä. Yrityksen aineetonta pääomaa. (In Finnish: "Functional Communication. Corporate intangible capital") In Aula, P. \& Hakala, S. (eds.) Kolmet kasvot. Näkökulmia organisaatioviestintään (In Finnish: "Three faces, approaches to organizational communication"). Loki-Kirjat: Helsinki, pp. $187-210$.

- Lin, N. (2005). A Network Theory of Social Capital. In Castiglione, D., van Deth, J. \& Wolleb, G. (eds.). Handbook on Social Capital, Oxford University Press: Oxford.

- Lin, N. (2001). Social Capital: A Theory of Social Structure and Action. Cambridge University Press: Cambridge.

- Lorenz, E. N. (1963). Deterministic nonperiodic flow. Journal of the Atmospheric Sciences: Vol. 20, No. 2, pp. 130-141.

- Luoma-aho, V. (2007). Reputation Formation of Innovations. A paper presented at the Fourth Conference on Innovation Journalism, "Journalism driving Innovation, Innovation driving Journalism”, Stanford University, USA, May 21 nd_23 2007.

- Luoma-aho, V. (2005). Faith-holders as Social Capital of Finnish Public Organizations. Jyväskylä Studies in Humanities, 42. University of Jyväskylä. [online] [cited 1.9.2006]. <URL: http://dissertations.jyu.fi/studhum/9513922626.pdf>

- Luoma-aho, V. (2005b). Viestintä, maine ja organisaation sosiaalinen pääoma (In Finnish: "Communication, Reputation and organizational social capital"). In Jokivuori, P. (ed.) Sosiaalisen pääoman kentät (In Finnish: "The fields of Social Capital") Minerva: Jyväskylä, pp. 393-413. 
- Markkanen, T-R. (1999). Yrityksen identiteetin johtaminen. Tulkintaa, viestintää ja sitoutumista. (In Finnish: "Management of corporate identity. Interpretation, communication and commitment") WSOY: Helsinki.

- Mitchell R., Agle, B. \& Wood D. (1997). Toward a Theory of Stakeholder Identification and Salience: Defining the Principle of Who and What Really Counts. Academy of Management Review. Vol. 22, No. 4, pp. 853 - 886.

- Näsi, J. (1979). Yrityksen suunnittelun perusteet. (In Finnish: "Foundations of Corporate Design") Yrityksen taloustieteen ja yksityisoikeuden laitoksen Julkaisuja A 1:15. University of Tampere.

- Ojala, J., Hakoluoto, T., Hjorth, A. \& Luoma-aho, V. (2006). Hyvä paha sosiaalinen pääoma (In Finnish: "Good and Bad Social Capital"). In Jokivuori, P., Latvakarjanmaa, R. \& Ropo, A. (eds.) Työelämän taitekohtia (In Finnish: “Turning points of working life"). Työpoliittinen tutkimus, Työministeriö: Helsinki.

- Patulny, R. (2003). Bonding, bridging and investment: important aspects of a national social capital policy strategy. Melbourne Journal of Politics. January 03.

- Pharoah, A. (2003). Corporate reputation: the boardroom challenge. Corporate Governance. Vol. 3, No. 4, pp. 46-51.

- Pizzorno, A. (2004). Resources of Social Capital: Reputation and Visibility. A presentation given at the ECSR Summer School on Social Capital, Trento Italy, August 22nd -27th, 2004.

- Putnam, R.D. (2000). Bowling Alone. The Collapse and Revival of American Community. Simon \& Schuster: New York.

- Putnam, R. D. (1993). Making Democracy Work. Princeton University Press: Princeton, NJ.

- Savage, G., Campbell, K., Patman, T. \& Nunnelley, L. (2000). Beyond Managed Costs. Current Trends and Future Issues. Health Care Management Review. Vol. 25, No. 1, pp. 93-108. 